\title{
Leber's disease with symptoms resembling disseminated sclerosis
}

\author{
F. LEES, A-M. E. MACDONALD, AND J. W. ALDREN TURNER \\ From the Department of Neurology, St. Bartholomew's Hospital, London
}

Hereditary optic neuritis was first clearly delineated by Theodore Leber in 1871 , and its occasional association with migraine, epilepsy, and retinitis pigmentosa is recognized.

In the family to be described an affected woman had five children, three of whom had Leber's disease. Two of these had neural symptoms and signs indistinguishable from disseminated sclerosis. In one, these symptoms coincided with acute bilateral Leber's optic neuritis, a phenomenon not previously reported.

Five generations of this family and our clinical observations in four living affected individuals are described.

\section{FAMILY HISTORY AND CLINICAL DESCRIPTIONS}

The diagrammatic pedigree is illustrated.

GENERATION I The only important information about this generation is that one man is known to have lost his sight at about 50 years of age.
GENERATION II This generation contained six unaffected females and two affected males.

Case II (I) went blind at the age of 50 and is dead. He had five unaffected daughters. There is no information about their children.

Case II (5) went blind aged 14 and died without issue at the age of 65 .

GENERATION III This generation contained 19 females, of whom two were affected, and 11 males, of whom six were affected.

Cases III (2) and III (3), sons of the same unaffected mother, both went blind at the age of 24 after emigrating to Australia.

Case III (9) went blind at an unknown age. His mother and his only daughter were unaffected.

Case III (17), the son of an unaffected mother, went blind at the age of 21 and died without issue.

Case III (22), the son of an unaffected mother, went blind at the age of 42 and is still alive at age 73. He has three unaffected daughters and one unaffected son.

Case III (23), the son of an unaffected mother, went blind at the age of 21 and is still alive aged 75 . In January

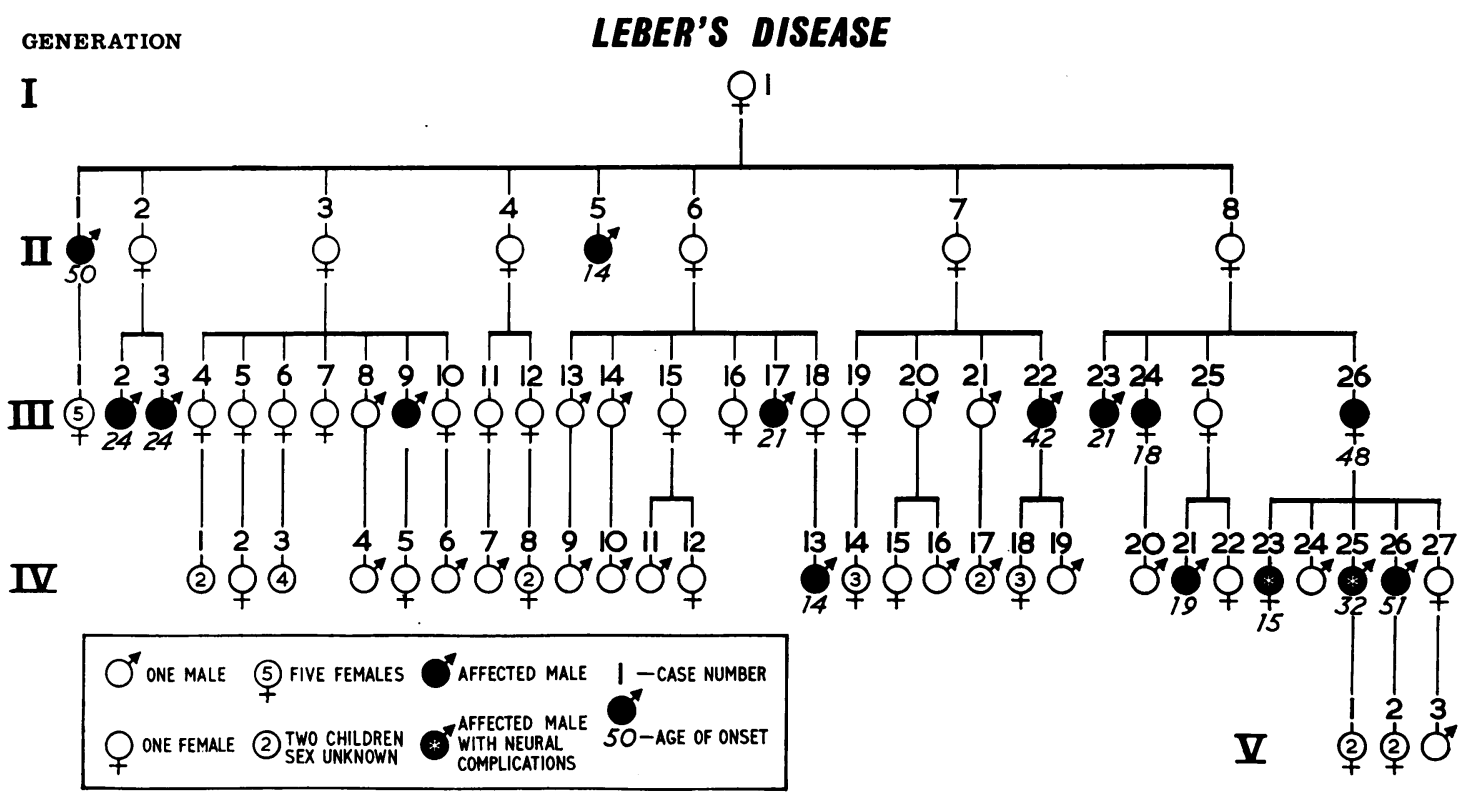


1963 he had an obstructed hernia and a hemiplegia from which he has recovered. He has no issue.

Case III (24) is the daughter of an unaffected mother. She went blind aged 18 and is now alive and well aged 67.

Case III (26) was the daughter of an unaffected mother. We saw her in Brighton at her home in February 1963. She is now 82 years of age and is fit and well apart from poor vision. At the age of 48 she was about to pick up her change from a counter while out shopping when she realized she could not see it. Since that moment, she has had large absolute central scotomata, easily demonstrated on confrontation. Examination also shows bilateral optic atrophy particularly affecting the temporal sides of the discs. She has useful peripheral vision and can watch the television out of the 'corner' of her eye.

GENERATION IV There are known to be at least 37 people in this generation. Of these, four males and one female are affected.

Case IV (13) is the son of an unaffected mother, who went blind aged 14 .

Case IV (21) is the son of an unaffected mother. He was seen at St. Bartholomew's Hospital in February 1963 aged 45 . He went blind suddenly aged 19 . The vision deteriorated for two months and then remained static. It has not changed for the last 26 years. He has no other symptoms. Examination showed large absolute central scotomata. He has some useful peripheral vision. He showed constant scanning movements of the eyes. The optic discs showed bilateral temporal pallor, well demonstrated on retinal photographs. There were no abnormal neurological signs. He is married but has no children.

Case IV (23) was the daughter of an affected mother. At the age of 15 her vision rapidly deteriorated so that eventually she could not read. She had no further symptoms until she was 21 years of age when she developed difficulty in walking. The right leg was weak and she could not control it properly. She was admitted to the Royal Sussex County Hospital under the care of Dr. Lyon-Smith. On examination there was generalized pallor of both optic discs most marked on the temporal sides. Visual fields were charted and showed fairly large central scotomata, most marked for red. There was no peripheral constriction of the fields. Visual acuity in the right eye was $6 / 9$ and in the left eye $6 / 36$. The pupils were normal. There was no nystagmus. Cranial nerve functions were otherwise normal. The abdominal reflexes were absent. There was right-sided ankle clonus. The right knee jerk was increased and plantar responses were extensor. A clinical diagnosis of disseminated sclerosis was made although it was noted that there was a family history of optic neuritis. The cerebrospinal fluid appeared normal; it contained 1 cell per c.mm., protein $30 \mathrm{mg} . \%$, and no excess of globulin. The colloidal gold curve was entirely negative and so was the Wassermann reaction. The mother and sister of this patient told us that she later developed numbness, tingling, and weakness in both hands. Her speech was slurred. She developed retention of urine, had flexor spasms in the legs, and was bedridden for two years. They noticed that she was always "bright and cheerful'. She died at the age of 26.

Case IV (25) was the son of an affected mother. He was seen in St. Bartholomew's Hospital in February 196\$ aged 37 . He told us that at the age of 32 he suddenl developed blurred vision in both eyes. After three weeks he was unable to read. The vision remained static for tw years, during which time he could not see to read or drive his car. He had severe loss of central vision so that 50 yards he could not see a double decker bus. He then began to improve over a period of 18 months. The scotoma in the right eye cleared partly from the centre but remained just below the centre of vision. The vision in the left eye did not improve and the scotoma remained. central. He is now able to drive his car and to read wort by word. He cannot thread a needle.

Examination showed constant scanning movements oळ the eyes and scotomata, as previously described. There was bilateral pallor of the temporal halves of both optien discs clearly seen on fundal photographs, as well as by ophthalmoscopic examination. There were no othe abnormal neurological signs or symptoms.

Case IV (26) was the son of an affected mother. HE was admitted to St. Bartholomew's Hospital on 23January 1963 at the age of 51 . He had been quite welt until the morning of 24 December 1962, when he found he could not read small print in his newspaper. He recog nized that the centre of his vision was blurred in bothp eyes. Within six hours he developed weakness of the lefi arm and ley which became progressively worse during the next two weeks, so that he was unable to walk unaidedis His left hand was weak and he had great difficulty holding a fork. There was no facial weakness. Becausegofo the hemiparesis he was admitted to Croydon Genega? Hospital for lumbar puncture. The fluid proved to be normal. Shortly afterwards he was transferred to $\mathbf{5}$ t. Bartholomew's Hospital.

Examination showed bilateral steep edged cente. scotomata more dense in the right eye than in the lew, and more pronounced for red. Vision in the right eye $2 / 60$ and in the left $6 / 9$. The optic discs were virtually: normal. The pupils were equal and reacted normally. There was no nystagmus nor any other abnormality in cranial nerve function. There was a considerable paresis affecting the left arm and leg but no sign of facial weak-음 ness. The reflexes in the left arm and leg were increased응 and the left plantar response was extensor. There was a slight increase in tone in the affected limbs. His blood $\vec{F}$ pressure was normal and there was no sign of cardio-을 vascular disease.

During the next five weeks power in the hemiparetic limbs gradually improved, although at discharge he still had increased reflexes and an extensor plantar response. He was then able to walk unsupported without sign of paresis. By this time there was obvious pallor of the temporal sides of both optic discs, well shown on comparison of retinal photographs taken at the time of ad- $\delta$ mission and five weeks later. The vision was $2 / 60$ in the right eye and $6 / 18$ in the left. Treatment consisted of 0 physiotherapy and a course of A.C.T.H. by intramuscular injection, starting with 80 units daily and gradually $\frac{7}{O}$ reducing the dose during the next 21 days. A total of 870 units was given.

Investigations, which included estimation of haemo- os globin, a white blood count and differential, a blood $N$ 
Wassermann reaction, radiographs of the skull, chest, and cervical spine, an electro-encephalogram and an air encephalogram, were all entirely negative or normal.

This patient had typical acute Leber's optic neuritis which persisted, associated with hemiparesis lasting for two months. If it had not been for the family history of Leber's disease he could well have been diagnosed as an unusual case of disseminated sclerosis with bilateral retrobulbar neuritis. Unlike his sister (case 23) he developed neural signs at the same time as the optic neuritis.

\section{DISCUSSION OF LEBER'S DISEASE}

Leber's disease is an inherited non-recurrent form of optic neuritis, nearly always affecting both nerves, to different degrees, within a period of a few days, weeks or months, and producing a rapid decline in central vision first for colours and then absolute. At first there may be an appearance of 'papillitis' or the optic disc may be normal; later there is pallor of the temporal half or the whole of the disc. Complete blindness is unusual, but the central scotomata are nearly always permanent with the preservation of some peripheral vision. The term 'Leber's optic atrophy' often suggests a chronic disease, but most well-documented cases have an acute onset indistinguishable from that of the retrobulbar neuritis of disseminated sclerosis. The failure to recover sight and the bilateral affection distinguish most cases of Leber's disease from the retrobulbar neuritis of disseminated sclerosis. (Leber, 1871, 1877; Rea, 1941; Van Bogaert, 1948; Neame and Williamson-Noble, 1951; Wilson, 1954; Duke-Elder, 1959). One eye may escape (Taylor, 1892). Occasional cases seem to make a good recovery (Leber, 1877; Nettleship, 1903, 1909; Batten 1909). Diagnosis may depend on the family history in the atypical cases.

In the family we have described here the onset of blurred vision was sudden and bilateral, with rapid deterioration, in all those cases which are welldocumented. Visual loss was severe except in case IV (25) who was able to drive a car, and case IV (26) who was able to see everything except for a small central scotoma in both eyes which prevented reading. Case IV (25) was lucky to have a paracentral scotoma in one eye with good central vision. There was a central scotoma in the other eye. This is an example of affection of fibres other than the papillomacular bundle (Wilson, 1954). The development of temporal pallor of the optic discs was photographically recorded in case IV (26). All those examined had optic atrophy.

AGE OF ONSET The age of onset of blindness in Leber's disease is very variable. Leber (1877) quoted 18 to 23 years but recognized exceptions. Klöpfer
(1898) found a range of from 6 to 67 years in 314 published cases. Onset may be at a similar age in the affected members of a family. Sometimes a progressive change in the age of onset (anticipation) may appear in siblings or in successive generations as described by Sedgwick (1862) and Nettleship (1909). It is said that women tend to be affected at a later age than men (Wilson, 1954), often at the menopause (Rea, 1941), but there are many exceptions (Nettleship, 1909), (Lundsgaard, 1944). Twins may be affected at the same age (King, 1939). The ages of onset in the affected members of our family are shown in the illustration. They were $50,14,24,24$, $21,42,21,14,19,32$, and 51 in males; 18,48 , and 15 in females. This is a remarkably large variance which, on a single gene hypothesis, suggests a fairly large environmental contribution to aetiology (Haldane, 1941).

RELATIVE FREQUENCY IN MALES AND FEMALES Its more frequent occurrence in men than in women is unquestioned. The highest female incidence $(30 \%)$ appears to be in Japanese pedigrees (Kawakami, 1926). Leber (1871) recognized its occurrence in women, but the fact was rather lost sight of until Waardenberg in 1924 showed that they acquired the disease in the same manner and often in the same degree as did their male relatives. In the collections of Hormuth (1901) there were 192 males and 29 females. In 53 families no women were affected and in 21 families some were. In the family described by Suckling (1887) there were more affected women than men. In our family three women and 13 men are known to have been affected.

HEREDITY The mode of inheritance of Leber's disease is complex and incompletely known.

The main facts upon which a genetic hypothesis should be based are: (1) males are much more commonly affected than females; (2) affected males do not pass on the disease to subsequent generations; and, (3) affected females rarely pass on the disease to their daughters.

It has been suggested that the abnormal gene is on the $\mathrm{X}$ chromosome and that this explains why unaffected females (carriers) pass it on to their sons (hemizygous males). To explain why the daughters of the carrier mothers are sometimes affected, the concept of 'partial or intermediate dominance' has been invoked. If the $\mathrm{X}$ chromosome theory were correct then half the daughters of affected males should be carriers and should pass on the disease to their sons. This does not occur. The theory is untenable.

Waardenberg (1948) suggested that hereditary particles in the cytoplasm of ova and sperms might 
be the agents of transmission (cytoplasmic theory). Because of the large amount of cytoplasm in the ovum and small amount in the sperm only females would transmit the disease. This theory is unacceptable because it does not explain why so few daughters of affected women are themselves affected.

The possibility of an autosomal abnormality does not seem to be likely because males do not transmit the disease.

It has been suggested to us that the Lyon inactivated $X$ dosage compensation theory (Lyon, 1961, 1962, 1963) might help to explain the clinical observations. This theory suggests that instead of the chromosomes of maternal and paternal origin being randomly inactivated in the female, the paternal $\mathrm{X}$ chromosomes (mutation carrying) are always the inactivated ones in the daughters. This selective inactivation takes place in very early zygote divisions. This theory has not yet been applied to Leber's disease.

Because the problems of inheritance in the disease are unsolved it is important that families should be reported in full so that more facts can be studied by geneticists.

Although the disease is inherited it only produces its effects in adult life and one cannot say more than that the liability to it is innate (Nettleship, 1909). The wide variation in age of onset suggests that some individuals, though genetically at risk, might not get the disease. The factors which precipitate the optic neuritis are unknown.

Nettleship (1909) stated that affected women pass on the disease in larger proportion to their issue than if they only carried it in the ordinary way (carrier state). This seems to apply to case III (26) who must have received the innate liability to the disease from her mother and grandmother who were both unaffected. Her husband was healthy and there was no consanguinity. Of her five children, three have been affected with Leber's disease. One daughter, case IV (23), also developed a disease clinically indistinguishable from disseminated sclerosis five years after the bilateral optic neuritis. One son, case IV (26), developed hemiplegia simultaneously with Leber's disease.

\section{DIFFERENTIAL DIAGNOSIS}

DOMINANT TYPES OF OPTIC ATROPHY Cases of dominant optic atrophy were described by Franceschetti (1930) and Scott (1941). The latter found 61 affected persons in two families. It affected both sexes by direct inheritance. The descendants of those not affected were free. Onset was at about 3 years of age. An example of hereditary optic atrophy both dominant and congenital was described by Thomp- son and Cashell (1935). In a family of six generations, 10 males and six females had congenital optic $\underset{\mathbb{D}}{Z}$

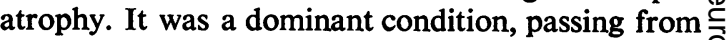
affected mothers but never via the father or unaffected mother. Peripheral field constriction as well $\frac{c}{6}$ as optic atrophy and nystagmus were the main 0 features. Five cases of congenital amblyopia with $\stackrel{\mathcal{N}}{\stackrel{2}{-}}$ optic atrophy and colour blindness but without $\stackrel{\rho}{=}$ central scotomata were described in three brothers $\stackrel{\overrightarrow{0}}{\overrightarrow{7}}$ and two sisters in a family by Snell (1897). The? parents were unaffected.

OPTIC ATROPHY ASSOCIATED WITH THE HEREDITARY ATAXIAS Although often mentioned in discussions on Leber's disease there is no difficulty in distinguishing this group. The optic atrophy is a minor feature, $\stackrel{\Omega}{\Omega}$ often being noticed on examination of the nervous is system. The patient does not complain of the acute $\overrightarrow{0}$ onset of blindness. Van Bogaert (1948) has reviewed this topic. Sjögren (1943) found optic atrophy in $12 \% \vec{\omega}$ of the Marie type of disease. The symptoms and 9 signs of the hereditary ataxia are gradual and progressive, not usually bearing any great resemblance to acute demyelinating diseases.

Van Bogaert (1948) described families whose or members had optic atrophy, hereditary ataxia, and $\vec{v}$ bilateral deafness due to demyelination of the 0 cochlear nerve roots. Van Leeuwen and Van Bogaeg (1949) described a few cases of acute retrobulbar $O$ neuritis in cases of hereditary ataxia.

CASES DESCRIBED BY BEHR In 1909, Behr described six patients with optic atrophy associated wim restriction of the peripheral vision. There were $\$$ pyramidal and cerebellar signs, slight intellectual impairment, poor bladder control, and degenerative stigmata. The onset was in infancy.

CASES DESCRIBED BY TAYLOR AND HOLMES Taylor $\frac{\circ}{8}$ and Holmes (1913) described patients with hereditary optic atrophy in whom the tendon reflexes were $\overline{\overline{0}}$ diminished or absent, especially in the legs. The patients had pains and paraesthesiae in the hands and feet and slight sphincter troubles. Peripheral vision was constricted in most of the patients. One had tabes dorsalis. At first sight this seems a heterogenous group. Taylor and Holmes expressly stated $\overline{3}$ that they did not believe that these cases belonged to the Friedrich, Marie, or Sanger-Brown groups of $\delta$ hereditary ataxias. A similar case, which has not previously been compared with those of Taylor and 음 and Holmes, was described by Batten (1909) in a $D$ 20-year-old cousin of two brothers with Leber's disease. He had bilateral retrobulbar neuritis $\mathbb{N}$ associated with cramps in the feet, numb fingers, $\Omega$ tremor of lips and chin, and absent knee jerks. 
FAMILY DESCRIBED BY FERGUSON AND CRITCHLEY Ferguson and Critchley (1928) described a family in which three members of one generation had optic atrophy. One had epilepsy and was mentally defective, besides having optic atrophy with central scotomata. His brother had optic atrophy with central scotomata but no other signs. Their sister developed sudden misty vision with papillitis in 1923. She had left optic atrophy at the time, with slight swelling of the disc. Examination then showed no other abnormal neural signs. The vision did not improve. In 1928 , at the age of 17 , she complained of pains and paraesthesiae in the legs, associated with unsteady walking. Examination showed optic atrophy, central scotomata, poor convergence, horizontal nystagmus, jerky hands and legs, brisk reflexes, and extensor plantar responses. There were sensory changes in both legs. She was ataxic and there was a degree of pes cavus. The cerebrospinal fluid contained 15 white cells per c.mm. Protein was $60 \mathrm{mg}$. \% with increased globulin. The Lange gold curve was 2113321000 with Wassermann and Kahn tests negative.

The authors were quite satisfied that they were dealing with Leber's disease in this family. The possibility of disseminated sclerosis in the girl could not be dismissed. It was 'rather a case of Leber's disease with neurological signs than of familial ataxia with an incidental optic atrophy'. They compared their family with that of Imamura and Ichikawa (1919).

CASES DESCRIBED BY RUTH LUNDSGAARD Lundsgaard (1944) described 20 pedigrees and 101 case histories of Leber's disease. We have found only one of her cases which is relevant to this discussion of neural complications. Case 42 had tremor of the hands for several years before the onset of visual affection. In 1930, at the age of 45 , he consulted an oculist because of failing vision. He was admitted to a neurological unit where disseminated sclerosis was diagnosed. He had optic atrophy with bilateral central scotomata. The plantar responses were extensor. He belonged to a family of $\mathbf{7 0}$ individuals in five generations in whom there were 10 cases of typical Leber's disease, nine in males and one in a female. He (case 42) was the son of an unaffected mother who had two blind brothers.

CASES DESCRIBED BY NETTLESHIP Nettleship (1909) stated that he had seen double chronic amblyopia with partial optic atrophy in a man of 76 whose daughter, aged 23, had acute retrobulbar neuritis with symptoms like disseminated sclerosis. He had also seen a man of 50 who had an attack of diplopia followed later by unilateral retrobulbar neuritis. His daughter had a left-sided retrobulbar neuritis 20 years later at the age of 23 'with threatenings of disseminated sclerosis'. These may be examples of familial disseminated sclerosis rather than of Leber's disease.

CASE DESCRIBED BY WILSON (1963) A paper by Wilson was published in 1963 after we had completed the study of our family. He described a man of 48 who had developed hereditary optic atrophy at the age of 26. The symptoms and signs at the age of 48 included difficulty in walking, pains, paraesthesiae, deterioration of memory, pathological laughing and crying, dysphagia, chest pain, and dyspnoea.

Examination showed poverty of facial movement, weakness of the palate, tremulous tongue, wasted hands and forearms, and generalized muscle fasciculation. The legs were spastic with increased tendon reflexes and extensor plantar responses. No objective sensory abnormality was recorded.

Much of this clinical description brings to mind the diagnosis of motor neurone disease associated with dementia but the cerebrospinal fluid contained 10 lymphocytes per c.mm. and $70 \mathrm{mg}$. protein per $100 \mathrm{ml}$. The Lange curve was paretic. Electrodiagnostic tests supported the impression of anterior horn cell disease.

This man belonged to a family of which 14 members in two generations had visual failure. Five others in this family were briefly described. One had spastic lower limbs with extensor plantar responses, paraesthesiae, and defective vibration sense. Another had 'ataxic paraplegia'. One had deafness and paraesthesiae only and, in another, these two symptoms were combined with loss of vibration sense and probable pyramidal signs. Another also had pyramidal and sensory changes and suffered from migraine. Wilson also described four more patients who had similar symptoms and signs. One of these, a man who had visual failure as a schoolboy and was diagnosed as having Parkinsonism in 1940 at the age of 29, deteriorated rapidly in 1950 with cardiac and sensory symptoms. There was also dementia, mental confusion, ataxia, slurred speech, and precipitancy of micturition. The necropsy on this patient showed a cardiac myopathy and, in addition to changes in the optic nerve, retinae and tracts, there were diffuse slight changes in the brain and spinal cord. These consisted of reduction in the number of cerebral cortical nerve cells, small regions of ischaemic necrosis in the corpus callosum, scattered loss of Purkinje cells in the cerebellum, and some demyelination and gliosis in the spinal cord.

DEVIC's DISEASE Devic's disease or 'neuromyelitis optica' is characterized by the acute onset of bilateral 
optic neuritis and myelitis. It has not been described in families with Leber's disease. The coincidence of bilateral optic neuritis with myelitis distinguishes Devic's disease from disseminated sclerosis (Brain, 1962).

FAMILIAL DISSEMINATED SCLEROSIS The prevalence of a familial incidence of disseminated sclerosis was studied by Allison and Millar (1954). There were 44 families with two or more affected members out of a total of 668 families, an incidence of $6.58 \%$. In the differential diagnosis of such cases the authors mention retrobulbar neuritis in two cases of hereditary spastic paraplegia (Bickerstaff, 1950).

No cases of Leber's disease were found in this large series of families with disseminated sclerosis in Northern Ireland. The features which distinguish Leber's disease from the retrobulbar neuritis of disseminated sclerosis were defined by Wilson (1954). They are the bilaterality at the acute stage and the frequency of absolute central scotoma at the chronic stage, the irregular forms assumed by the scotoma, the failure to recover, and the predilection for males as well as the heredo-familial character of the disease.

NATURE OF LEBER'S DISEASE Three necropsy reports are available which indicate the pathological changes to be seen in the visual pathways in Leber's disease: those of Rehsteiner (1930), quoted by Wilson (1954); the case of Kwittken and Barest (1958), quoted by Wilson (1963); and the case examined by Professor Blackwood and described by Wilson (1963).

The optic nerve is demyelinated and shows atrophy of the papillomacular bundle. There is also transneuronal degeneration in the whole optic tract except the calcarine cortex. Brief details of the pathological findings in the rest of the nervous system in a patient with rapidly progressive and widespread symptoms and signs are available only in the case of Wilson (1963) and have already been mentioned. Whether these changes would also be found in other patients with Leber's disease who have signs and symptoms outside the visual pathways is as yet uncertain. The clinical picture of Wilson's (1963) case is in many respects unlike those which we have reviewed and also unlike the relevant cases in our family, both in symptoms and progress. It seems possible that a number of different pathological states might occur in patients who have had Leber's disease and with so few pathological studies available it would be rash to generalize.

\section{DISCUSSION}

It is likely that Leber's disease is a 'demyelinating' disease affecting the optic nerve and in particular the papillomacular bundle of fibres. The factors which precipitate the onset in the susceptible adult are unknown. Neither is it known with certainty what precipitates an attack of demyelination in disseminated sclerosis which, like Leber's disease, may be hereditary but by no means to the same degree.

The nature of susceptibility in these two diseases is not known and, in spite of the numerous pedigrees of Leber's disease, its heredity is still not understood. Neither is it known why certain families are more liable than others to suffer from disseminated sclerosis. In the pedigree we have described the two diseases seem to fuse in one family. It seems to be the meeting point of the two diseases. Could it not be a doubly heightened susceptibility in which the nervous system at a given moment and in response of to as yet undiscovered factors begins to show wide- $\vec{\circ}$ spread damage? The coincidental occurrence of disseminated sclerosis and Leber's disease in this family is excluded by the onset of hemiplegia at the same time as acute Leber's disease in a unique case.

Cases described in the literature which suggest a possible relationship between the two diseases are a case of Ferguson and Critchley (1928) and one of Lundsgaard (1944). These are the only well-docie $\vec{v}$ mented cases which seem to be of disseminated sclerosis and Leber's disease with definite pedigrees

There is no real difficulty in recognizing the othew conditions in which optic neuritis or optic atroph\& may be seen and which we have briefly reviewed. $\frac{0}{0}$

The patients described by Wilson (1963) are now. much like cases of disseminated sclerosis. At leas $\vec{\bullet}$ one resembled motor neurone disease with dementia. $₫$ The case which was examined at necropsy showed widespread neurological changes and cardiac disease. The neurological changes outside the visual tracts were rather non-specific. However, this necropsy did show that the changes were unlike those of disseminated sclerosis. Whether other cases would show a different histology will remain uncertain until more pathological data are available.

The importance of our family is that it appears to demonstrate the factor of 'susceptibility' or 'innate liability' in what is in part a demyelinating process. The environmental factors which might precipitate neurological symptoms in this disease are at present unknown. The possibility that smoking has played a part was discussed by Taylor (1892) and has again been raised by Wilson (1963). This could only apply to some patients; the two members of our family who had widespread neurological symptoms did not smoke.

Another point worth considering is that of treatment. There is some evidence that A.C.T.H. might favourably influence the progress of acute lesions in

.


disseminated sclerosis (Miller, Newell, and Ridley, 1961). Might we not also be well advised to give A.C.T.H. immediately at the onset of visual symptoms in persons known to be at risk in Leber families? There is no known effective therapy and in the majority of cases blindness is permanent in this disease. If such therapy is to be given a chance to be effective, members of the family should be advised to attend the appropriate medical adviser at the very onset of symptoms of optic neuritis.

\section{SUMMARY}

A pedigree showing five generations of Leber's disease is presented. In one family three of the five children of an affected mother had the disease. Two of them also had involvement of other parts of the nervous system clinically indistinguishable from disseminated sclerosis.

The features of Leber's disease and its differential diagnosis are described with especial reference to optic atrophy associated with other neural syndromes.

Theoretical implications are discussed and the possible value of A.C.T.H. in the treatment of acute Leber's disease is considered.

We wish to thank Mr. K. G. Ellis-Martin, the Group Medical Records Officer, the Royal Sussex County Hospital, for his help in making available the records of case 13.

We also thank Mr. J. H. Dobree for his help in the examination of the patients.

\section{REFERENCES}

Allison, R. S., and Millar, J. H. D. (1954). Prevalence and familial incidence of disseminated sclerosis. Ulster med. J., suppl. 2 to vol. 23.

Batten, R. (1909). Two cases of hereditary optic atrophy in a family, with recovery in one case. Trans. ophthal. Soc. U.K., 29, 144-150.

Behr, C. (1909). Die komplizierte hereditär-familiäre Optikusatrophie des Kindesalters. Klin. Mbl. Augenheilk., 47, (ii), 138-160.

Bickerstaff, E. R. (1950). Hereditary spastic paraplegia. J. Neurol. Neurosurg. Psychiat., 13, 134-145.

Brain, Lord (1962). Diseases of the Nervous System, 6th ed., p. 446 Oxford University Press, London.

Duke-Elder, S. (1959). Parsons' Diseases of the Eye, 13th ed., p. 358. Churchill, London.

Ferguson, F. R., and Critchley, M. (1928). Leber's optic atrophy and its relationship with the heredo-familial ataxias. J. Neurol. Psychopath., 9, 120-132.

Franceschetti, A. (1930). In Kurzes Handbuch der Ophthalmologie, edited by F. Schieck and A. Brückner, vol, 1, p. 801. Springer, Berlin.

Haldane, J. B. S. (1941). The relative importance of principal and modifying genes in determining some human diseases. $J$. Genet., 41, 149-157.
Hormuth, P. (1901). Beiträge zur Lehr von den hereditären Sehnervenleiden. Beitr. Augenheilk., 5, 63-227. [Heft 42].

Imamura, S., and Ichikawa, K. (1919). Atrophie optique familiale avec tremblement et déchéance intellectuelle. Rev. neurol., 26, 277-282.

Kawakami, R. (1926). Beiträge zur Verebung der familiären Sehneřvenatrophie. Albrecht v. Graefes Arch. Ophthal., 116, 568-595.

King. E. F. (1939). Leber's disease in twins. Proc. roy. Soc. Med., 32, 763-764.

Klöpfer, G. L. (1898). Inaug. Dis., Tubingen. (Quoted by S. A. Kinnier Wilson, 1954.)

Kwittken, J., and Barest, H. D. (1958). The neuropathology of hereditary optic atrophy (Leber's disease): the first complete anatomic study. Amer. J. Path., 34, 185-207.

Leber, T. (1871). Ueber hereditäre and congenital-angelegte Sehnervenleiden. Albrecht v. Graefes Arch. Ophthal., 17, pt. 2, pp. 249-291.

- (1877). Die Neuritis optica in Folge von Heredität und congenitaler Anlage. In Handbuch der gesammten Augenheilkunde, edited by A. Graefe and T. Saemisch, Band 5, Theil iii, pp. 824-828. Engelmann, Leipzig.

Lundsgaard, R. (1944). Leber's Disease. Acta ophthal. (Kbh.), suppl. 21.

Lyon, M. F. (1961). Gene action in the X-chromosome of the mouse. Nature (Lond.), 190, 372-373.

- (1962). Sex chromatin and gene action in the mammalian X-chromosome. Amer. J. hum. Genet., 14, 135-148.

- (1963). Attempts to test the inactive-X theory of dosage compensation in mammals. Genet. Res., 4, 93-103.

Miller, H., Newell, D. J., and Ridley, A. (1961). Multiple sclerosis treatment of acute exacerbations with corticotrophin (A.C.T.H.). Lancet, 2, 1120-1122.

Neame, H., and Williamson-Noble, F. A. (1951). A Handbook of Ophthalmology, 7th ed., p. 194. Churchill, London.

Nettleship, E. (1903). A case of family optic neuritis (Leber's disease) in which perfect recovery of sight took place. Trans. Ophthal. Soc. U.K., 23, 108-112.

(1909). On some hereditary diseases of the eye. Ibid., 29, LVIICXCVIII.

Rea, R. L. (1941). Neuro-ophthalmology, 2nd ed., p. 103. Heinemann, London.

Rehsteiner, K. (1930). Der erste anatomische Befund bei geschlechtsgebunden-hereditärer Sehnervenatrophie (Leber'scher Krankheit) Schweiz. med. Wschr., 11, 122-124.

Scott, J. G. (1941). Hereditary optic atrophy with dominant transmission and early onset. Brit. J. Ophthal., 25, 461-479.

Sedgwick (1862). Hereditary amaurosis. Med. Times Gaz., 1, 309.

Sïorgen, T. (1943). Klinische und erbbiologische Untersuchungen uber die Heredoataxien. Acta Psychiat. et Neurol., suppl. 27.

Snell, S. (1897). Diseases of the optic nerve. I. Hereditary or congenital optic atrophy and allied cases. Trans. Ophthal. Soc. U.K., 17, 66-81.

Suckling, C. W. (1887). Hereditary optic atrophy. Lancet, 2, 1271.

Taylor, S. J. (1892). Diseases of the optic nerve, I. Hereditary optic atrophy, Trans, Ophthal. Soc. U.K., 12, 146-156.

Taylor, J., and Ho!mes, G. M. (1913). Nervous symptoms associated with optic atrophy of the familial type. Ibid., 33, 116-138.

Thompson, A. H., and Cashell, G. T. W. (1935). A pedigree of congenital optic atrophy embracing sixteen affected cases in six generations. Proc. roy. Soc. Med., 28, 1415-1425.

Van Bogaert, L. (1948). Hereditary optic atrophy as a manifestation of the heredo-ataxias. In Modern Trends in Ophthalmology. edited by A. Sorsby, vol. 2, pp. 317-331. Butterworth, London.

Van Leeuwen, M., and Van Bogaert, L. (1949). Hereditary ataxia with optic atrophy of the retrobulbar neuritis type and laten pallido-luysian degeneration. Brain, 86, 340-363.

Waardenberg, P. J. (1948). Some genetic aspects. In Modern Trends in Ophthalmology, edited by A. Sorsby. pp. 169-187. Butterworth, London. (Leber's Disease. p. 180.)

Wilson, J. (1963). Leber's hereditary optic atrophy. Some clinical and aetiological considerations. Brain, 86, 347-362.

Wilson, S. A. Kinnier (1954). Neurology, 2nd ed., edited by A. N. Bruce, vol. 2, pp. 1061-1070. Butterworth, London. 